\title{
Alzheimer's desease: challenges faced by family caregivers
}

Luciane Salete Kucmanski' Leoni Zenevicz'

Daniela Savi Geremia? Valeria Silvana Faganello Madureiral Tatiana Gaffuri da Silva' Sílvia Silva de Souza'

\section{Abstract}

Gaps identified in Brazilian health policies and the need to develop and implement strategies for the empowerment and monitoring of family caregivers support the development of care proposals aimed at the family. The present study aimed to analyze the challenges faced by family members providing day to day care of patients with Alzheimer's disease in the city of Chapecó, Santa Catarina. The method employed was the qualitative approach through semi-structured interviews. The speeches were grouped, categorized and analyzed using the hermeneutic method. The results showed that during the period of Alzheimer's disease, caregivers experience a range of situations, including: a need to Alzheimer Disease. Aging. learn about the disease; dealing with guilt; and handling situations of pain, addiction and physical and psychological suffering. In conclusion the study described the challenges of the daily lives of these families, explaining the importance of and highlighting the need to adopt tools and strategies that provide physical, emotional, psychological and financial support to family caregivers of patients with Alzheimer's disease.

Universidade Federal da Fronteira Sul, Curso de Graduação em Enfermagem. Chapecó, Santa Catarina, Brasil. 


\section{INTRODUCTION}

The phenomenon of epidemiological transition, conditioned by the process of population aging, is determinant on the emergence of chronicdegenerative diseases, among them Alzheimer's Disease (AD), demanding continuous care and new organizational structures for networks and health services $^{1-3}$.

In Brazil, AD is responsible for $50 \%$ to $60 \%$ of dementia cases among the elderly population. It is considered to be a neurological and degenerative disease and a type of senile dementia with a progressive and complex evolution ${ }^{4}$.

The exact cause is unknown, but the decrease in acetylcholine, cranial traumas, viral infections, genetic factors and the presence of beta-amyloid protein are suggestive of its emergence. Progressive and irreversible, $\mathrm{AD}$ results in memory and cognition disorders, incapacitating the individual for self-care ${ }^{5}$.

According to the Associação Brasileira de Alzheimer (the Brazilian Alzheimer's Association) (ABRAZ), AD is a dementia characterized by three major phases. It starts with forgetfulness and subtle loss of memory and difficulties at work. It can be confused with depressive states, and progresses through more severe memory loss and the inability to perform complex tasks such as calculations and planning. The third stage is manifested by the marked impairment of functional capacity, such as difficulty in eating, dressing and bathing ${ }^{4}$.

Prospective studies show that by 2050 AD may affect 14 million people worldwide. It is considered the fourth leading cause of death in adults ${ }^{6}$.

In this context, the role of the caregiver emerges as a fundamental element of home care, responsible for caring for the patient, providing for his or her basic needs, performing/assisting with activities of daily living, and caring for themselves and often many other members of the family, such as children, wives, or grandchildren?

Caring for elderly people with Alzheimer's is an arduous task. The caregiver often does not devote sufficient attention to their own needs, due to the daily demands of care, including comfort, safety, help in activities of daily living (ADL) and tasks related to domestic chores.

The primary caregiver is directly responsible for all these actions. In contrast. While secondary caregivers may perform the same tasks as the primary caregiver, they do not have the same level of responsibility and decision-making authority. Tertiary caregivers are supportive, replacing the primary caregiver for short periods, and usually perform specialized tasks such as shopping, assisting in patient transportation, collecting pensions, and paying bills. While all play an important role in care, it is clear that the responsibility for providing care and attention rest with the primary caregiver.

In this context, the aim of the present study was to analyze the main difficulties of family caregivers of sufferers of Alzheimer's Disease in the city of Chapecó, in the state of Santa Catarina.

\section{METHOD}

A qualitative, descriptive study was performed of eight family caregivers of patients with AD living in the municipality of Chapecó, in the state of Santa Catarina. All were participants of the Support Group for Caregivers of Alzheimer Patients. The inclusion criteria adopted were: having been a family caregiver of elderly persons with AD for one year or more, while living in the same household.

The study was approved by the Ethics Research Committee of the Universidade Comunitária da Região de Chapecó (the Community University of the Chapecó Region) (UNOCHAPECÓ), under record $\mathrm{n}^{\mathrm{o}} 216 / 12$. The hermeneutics ${ }^{8}$ method was used to analyze the discourses, following four steps: initial reading of the text, distancing, structural analysis, deeper understanding and appropriation?

From the analytical model adopted, the data was organized into four analysis categories to enable the grouping of the answers obtained and discussion about the discourses. In each of the four categories different aspects of care were perceived, which were organized into subcategories. The identity of the participants was preserved and it was decided to denominate their discourses with names of flowers. 
The results will be presented based on the socioeconomic and demographic profile of the caregivers of family members with AD (Table 1). Subsequently, results will be presented through the analysis of a category and its subcategories.

\section{RESULTS AND DISCUSSION}

The caregivers participating in this study were aged between 47 and 80 years, and the primary family caregivers were predominantly women. There were equal numbers of married and divorced women, and the Catholic religion predominated. In terms of income, most caregivers received from one to four minimum wages. It should be emphasized that socioeconomic variables increase the physical, emotional, social and financial difficulties of caregivers (Table 1).

Another factor exhibited was the religion professed by the attending caregivers. All had a basis in Christianity. Knowing the religion of each person is important because, in general, it is through religious practices that caregivers express their spirituality (Table 1).

Table 1. Socioeconomic and demographic profile of caregivers of family members with Alzheimer's Disease. Chapecó, Santa Catarina

\begin{tabular}{lccllll}
\hline Data & Gender & Age & Marital Status & Schooling & $\begin{array}{l}\text { Income } \\
\text { (minimum salary) }\end{array}$ & Religion \\
\hline Daisy & F & 64 & Widowed & $\begin{array}{l}\text { Elementary } \\
\text { Incomplete }\end{array}$ & 1 to 4 & $\begin{array}{l}\text { Evangelical } \\
\text { Protestant }\end{array}$ \\
\hline Clove & M & 80 & Married & $\begin{array}{l}\text { Elementary } \\
\text { Incomplete }\end{array}$ & 1 to 4 & Catholic \\
\hline Hydrangea & F & 53 & Divorced & $\begin{array}{l}\text { Graduation } \\
\text { incomplete }\end{array}$ & 5 to 9 & Catholic \\
\hline Dahlia & F & 51 & Married & Masters & 5 to 9 & Catholic \\
\hline Violet & F & 55 & Divorced & $\begin{array}{l}\text { Graduation } \\
\text { incomplete }\end{array}$ & 1 to 4 & Catholic \\
\hline Orchid & F & 61 & Married & $\begin{array}{l}\text { Graduation } \\
\text { Incomplete }\end{array}$ & 5 to 9 & Lutheran \\
\hline Rose & F & 52 & Divorced & Post-graduate & 1 to 4 & Catholic \\
\hline Begonia & F & 47 & Single & Post-graduate & 1 to 4 & Spiritualist \\
\hline
\end{tabular}

F: female; M: male

In a study carried out at the geriatrics and neurology outpatient clinic of the Base Hospital of São José do Rio Preto, São Paulo, eight Alzheimer's caregivers were predominantly female and $50 \%$ were married, with elementary education and advanced age ${ }^{10}$.

The fact that caregivers are mostly female can be attributed to the historical division of labor between men and women and the gender differences that attribute the care of other family members to women. In this sense, women themselves may consider care as a mission and the focus of their existence, related to giving birth, which connects them to all aspects of life and care ${ }^{11}$. In addition, female dominance occurs because the female population of the planet is greater. This affirmation also follows the cultural norms that expect men to provide sustenance and authority and women to care for the children, the house and the elderly ${ }^{12}$.

In the opinion of Boff ${ }^{13}$, care is,

More than an action: it is an attitude. Therefore, it covers more than the moment of attention, of zeal and care. It represents an occupation and attitude of concern, responsibility and involvement with another. 
Care has an existential character and arises when the caregiver understands their own subjectivity and that of the individual receiving the care, with this relationship expressing itself in such a way that the individuality, autonomy and freedom of the other are respected ${ }^{14}$.

Waldow ${ }^{15}$ added that

OThe Human Being is a Being of care, born with this potential. Everyone, therefore, is able to take care of someone and also needs to be cared for.

Following the general characterization of the profile of the participants, the analysis of the discourse of the interviews was categorized as follows:

Category I - Difficulties in the care of family members with Alzheimer's disease

Regarding the difficulties encountered in the care of individuals with $\mathrm{AD}$, the data analysis revealed three main aspects: hygiene and comfort, a constant need for attention and a lack of knowledge about the disease.

\section{Subcategory I. Hygiene and Comfort}

The limitations of patients with AD involve an inability to perform activities of daily living (ADL) and require the family caregiver to be constantly present in tasks of hygiene and comfort, exacerbating feelings in the caregiver that oscillate between anger, due to the stubbornness of the patient, and pity, due to having a family member with a progressive and irreversible disease ${ }^{16}$.

In this subcategory, bathing, combined or not with the resistance of the patient, stood out, as can be seen in the following statement:

"It's my mother's resistance to bathing, she resists and fights a lot, she does not want to bathe at all" (Begonia).

"It's giving her a bath, when she's calm, it's fine, if she gets upset she resists, so I have to let her do some little things" (Clove).
"The most demanding task is her personal hygiene, helping her bathe, it's what worries me the most and is the most demanding" (Orchid).

Other difficulties with personal hygiene (teeth) were discussed, while the musculoskeletal problems of the caregiver also make the provision of care difficult:

"The greatest difficulties I have with taking care of my brother with Alzheimer's are brushing his teeth because he forgets, and bathing, because I have to lower myself and I have spinal problems and a lot of pain in my body" (Daisy).

There are other difficulties arising from secondary complications of the pathological processes of the AD patient which also make care difficult:

"Well, I don't think there is a specific task, it is the group of small tasks that go on all day, personal hygiene and food, because she recently underwent bowel surgery and had an ileostomy. This further aggravated her health" (Dahlia).

The daily tasks of the caregiver are influenced by the limitations imposed by AD, by the additional pathological processes of the AD sufferer, and especially by the health conditions of the caregiver themselves.

\section{Subcategory 2. Constant need for attention}

This subcategory identifies the constant attention required by elderly relatives with $\mathrm{AD}$ as one of the challenges faced by caregivers, as the discourses confirm:

"Manage what she does. Accept what she does. Follow her closely, stay close to her. You have to be constantly supervising what she does, because she no longer sees the extent of the danger of what she is doing" (Violet).

"What requires the most from me is caring for her when she has crises. This is a very difficult type of care, because you have to stay on top of it 24 hours a day" (Hydrangea) 
"My greatest difficulty is paying constant attention because she is very forgetful and often puts herself at risk when she is near cleaning products. A few days ago we found her wanting to drink detergent. So I believe that my main difficulty is having to always pay attention so as not to let her get into danger" (Dahlia).

A study of family caregivers carried out at the neurology department of the Hospital de Clínicas in Porto Alegre, Rio Grande do Sul, found that intensive care and attention are necessary in ADL mainly due to the impairments caused by the disease and the loss of autonomy and independence that result from $\mathrm{it}^{17}$.

The dependency that makes a caregiver necessary is revealed by an inability to care for oneself satisfactorily without the help of others, as well as in the loss of decision-making capacity ${ }^{18}$.

According to the International Classification of Functioning, Disability and Health (ICF), activity limitations are difficulties that an individual may have in performing activities, and the capacity and ability of an individual to perform a task or action ${ }^{19}$. Dependence is a condition of elderly persons, the basic characteristic of which is the degeneracy resulting from chronic diseases or other pathologies, which threatens their physical, social and economic integrity, diminishing or impeding the individual's ability to meet his or her needs ${ }^{20}$.

Another aspect highlighted in the discourse presented was the shocks that the caregiver suffers due to the situations of risk in which the patient is involved, which generates anguish, fears and ambivalent feelings towards the individual receiving care. This situation is reinforced by Brum et al. ${ }^{21}$.

In the dependency phase, the changes that take place in the new life dynamic of the caregiver completely change his or her daily life. These include preparing food, administering medications, establishing a routine for exercises and activities of comfort, including personal hygiene, hair combing, teeth brushing, fingernail cutting, dressing, undressing, moving from one place to another, climbing stairs, sitting, getting up, and lying down, among many other activities.

\section{Subcategory 3. Lack of knowledge about disease}

This subcategory revealed a fundamental difficulty for family caregivers regarding the caring process. It refers to knowledge of the disease and its evolution.

The interviews frequently expressed the view that their difficulties would be lessened if they had known in advance about the possible situations that could occur and how to act when faced with each one of them. This fact is evidenced in the statements of three participants.

"The main difficulty is to understand how this
works in her mind. [...] to understand how things
go through her mind and the best way to coexist,
in order not to cause her any more pain than she
has already suffered. We do not understand many
things that have happened to her" (Rose).

"My worry is knowing when I should take her to the doctor. Because if she doesn't urinate, I have to give her medicine to make her do it. It's the same thing with defecation. She refuses to eat and we worry about whether it's time to take her to the doctor or not" (Begonia).

"I don't know if I'm doing exactly what we set out to do. I'd like to serve her, to know and understand better what's going on in her head. How best to care for her and how best to maintain the little she has when she is living with us" (Orchid)..

The exercise of caring for an elderly patient at home is a constant learning process, based on the physical and biological needs of the individual and his or her level of dependence. In most cases, it is difficult, due to the inexperience of the caregiver, to meet the demands that arise during the process of caring and which must be learnt to meet the challenges of everyday life. Activities that seem simple to those who have already developed them become arduous for those who have never had to confront them.

As the data indicates, ignorance of $\mathrm{AD}$ is a crucial point for caregivers, especially as care in Brazil is curative and centered on the individual, with teams working in a fragmented manner, which devalues the family situation and the sociocultural context ${ }^{1}$. 
In this sense, it is imperative that caregivers are constantly monitored and receive guidance on the evolution of the disease, as well as on the care needed at each stage. This is necessary for efficient care, which results in safety and support, to be provided, and can foster an information exchange network capable of minimizing the stress of the family caregiver ${ }^{15}$.

Better informed and more experienced caregivers are less anxious and more secure in their provision of care, which is reflected in a greater capacity and availability to take care of the patient. Health and social institutions should make all their information available to the caregiver. Nurses can jointly propose a care plan to delay the degenerative effects of $A D$ and allow the elderly person to live with the signs and symptoms in the best possible way.

Studies ${ }^{22,23}$ have indicated a significant gap in the life and health of the caregiver, specifically the need for health professionals to provide understandable explanations, exchange experiences, and promote openness and dialogue about the disease so that care can be performed safely at home.

Thus, getting to know families that welcome subjects with $\mathrm{AD}$, who they are, what they do, where they work and other characteristics, can help in the organization of their routines, reducing situations of conflict and supporting the frailties imposed by the disease.

During the interviews, it was perceived that each caregiver of $\mathrm{AD}$ patients presented individual peculiarities in their discourses about care, as the singularity of the disease in each patient, the length of time each caregiver has cared for their family member and even the time of discovery of the diagnosis are limiting factors for a generalization about the challenges faced in everyday life. Thus, it is important to consider the specific profiles of patients with $A D$ and the contexts involved in the exercise of care for the elderly. This information would be of great value for future studies. In the present study, all the interviewees had at least one year of experience and the technique used data saturation to guarantee the reliability of the results of the discourses presented and analyzed.

\section{CONCLUSION}

This study provided information about part of the daily life of those who act as caregivers of elderly people with Alzheimer's Disease, as well as the difficulties, emotions, limitations, and stress they face, but also the dedication with which they take care of their family member. The participants of this study were predominantly women, married or divorced, descendants of Italians, Catholic, with a family income of one to four minimum wages and with differentiated levels of schooling.

Greater life expectancy brings with it greater risks of developing dementias such as Alzheimer's Disease, patients of which require home care, resulting in changes in the daily lives of many families. The present study found that, when caring for a family member with Alzheimer's Disease, the caregiver experiences different feelings and requires attention and care from health professionals and public policies. While secondary and tertiary caregivers deserve our attention, it is the primary caregiver who carries the greatest burden and needs the most support. Caring for a family member with Alzheimer's Disease requires the caregiver to learn to live with the suffering of another, often having to disguise their own pain and needs. They are required to do almost everything, whilst knowing almost nothing. In addition, cohabitation with a family member with Alzheimer's Disease requires that the caregiver renounces many aspects of his or her personal life for the benefit of another, which increases the risk of personal and family illness.

It is the responsibility of health professionals to develop practices that seek and enable dialogues, respecting the knowledge, beliefs and environments of caregivers while providing training to caregivers with the purpose of guaranteeing quality care for Alzheimer's Disease patients and support for the caregiver. In this sense, by providing assistance to caregivers, professionals who are capable of guiding and intervening in the face of family conflicts and challenges, contribute to supporting those experiencing moments of frailty.

The current reality in Brazil, especially in relation to increasing population aging, requires urgent 
government measures of social and health care that encourage the family as a place of care. What can be verified, however, is that Brazilian public policies still exclude and marginalizing the poorest and neediest sectors, including those with Alzheimer's Disease.

There is, however, an urgent need for attention to be paid to these family caregivers, especially from public authorities, through the provision of trained professionals to deal with families, and not just patients. This issue is crucial for the family caregiver, since it requires health professionals to provide clear information, as well as objective and comprehensible skills related to the disease, its symptoms and its progression. In this way, the caregiver will be prepared to provide safer and less stressful home care.

\section{REFERENCES}

1. Vieira CPB, Gomes EB, Fialho AVM, Rodrigues DP, Moreira TMM, Queiroz MVO. Prática educativa para autonomia do cuidador informal de idosos. REME Rev Min Enferm. 2011;15(1):135-40.

2. Araujo I, Paul C, Martins M. Viver com mais idade em contexto familiar: dependência no auto cuidado. Rev. Esc. Enferm. USP. 2011;45(4):869-75.

3. Zenevicz LT. A dimensão espiritual no processo de viver envelhecendo [tese]. Porto Alegre: Pontíficia Universidade Católica do Rio Grande do Sul; 2009.

4. Associação Brasileira de Alzheimer. Número de pacientes deve aumentar nos próximos vinte anos [Internet]. São Paulo: ABRAZ; 2010 [acesso em 05 mar. 2012]. Disponível em: www.abraz.com.br

5. Gonçalves EG, Carmo JS. Diagnóstico da doença de Alzheimer na população brasileira: um levantamento bibliográfico. Rev Psicol Saúde. 2012;4(2):170-76.

6. Melo A. Dificuldades sentidas pelo cuidador de um Doente de Alzheimer: revisão bibliográfica [trabalho de conclusão de curso]. Porto: Faculdade Ciências da Saúde da Universidade Fernando Pessoa; 2010.

7. Neumann SMF, Dias CMSB. Doença de Alzheimer: o que muda na vida do familiar cuidador? Rev Psicol Saúde. 2013;5(1):10-7.

8. Ricoeur P. Teoria da interpretação: o discurso e o excesso de significação. Lisboa: Edições 70; 2016.

9. Crossetti MGO. Processo de cuidar: uma aproximação à questão existencial na enfermagem [tese]. Florianópolis: Universidade Federal de Santa Catarina; 1997.

10. Caldeira APS, Ribeiro RCHM. O enfrentamento do cuidador do idoso com Alzheimer. Arq Ciênc Saúde. 2004;11(2):1-4.
11. Sena RR, Silva HF, Vivas KL, Queiroz CM, Barreto FO. O cotidiano da cuidadora no domicílio: desafios de um fazer solitário. Rev. Cogitare Enferm. 2006;11(2):124-32.

12. Martins JJ, Albuquerque GL, Nascimento ERP, Barra DCC, Souza WGA, Pacheco WNS. Necessidades de educação em saúde dos cuidadores de pessoas idosas. Texto \& Contexto Enferm. 2007;16(2):254-62.

13. Boff L. Saber cuidar: ética do humano, compaixão pela terra. 9a ed. Petrópolis: Vozes; 2004.

14. Vale EG, Pagliuca LMF. Construção de um conceito de cuidado de enfermagem: contribuição para o ensino de graduação. Rev Bras Enferm [Internet]. 2011 [acesso em 26 ago. 2016];64(1):106-13. Disponível em: http:// www.scielo.br/scielo.php?script=sci_arttext\&pid =S0034-71672011000100016

15. Waldow VR. Maneiras de cuidar e maneiras de ensinar. Porto Alegre: Artes Médicas; 1995.

16. Caldas CP. Contribuindo para a construção da rede de cuidados: trabalhando com a família do idoso portador de síndrome demencial. Textos Envelhec. 2002;4(8):39-56.

17. Araujo JS, Vidal GM, Brito FN, Gonçalves DCA, Leite DKM, Dutra CDT, ET al. Perfil dos cuidadores e as dificuldades enfrentadas no cuidado ao idoso, em Ananindeua, PA. Rev Bras Geriatr Gerontol. 2013;16(1):149-58.

18. Luzardo AR, Waldman BF. Atenção ao familiar cuidador do idoso com doença de Alzheimer. Rev Acta Sci. 2004;26(1):135-45.

19. Associação Portuguesa de Enfermeiros de Reabilitação. Padrões de qualidade dos cuidados especializados em enfermagem de reabilitação. Porto: APER; 2011. 
20. Araujo PMC. Processo de ensino dinâmico a familiares cuidadores de doentes dependentes: contributo do enfermeiro de reabilitação a partir de um ensino estruturado [Dissertação]. Porto: Escola Superior de Enfermagem do Porto; 2012.

21. Brum AKR, Camacho ACLF, Valente GSC, Sá SPC, Lindolpho MC, Louredo DS. Programa para cuidadores de idosos com demência: relato de experiência. Rev Bras Enferm. 2013;66(4):619-24.
22. Seima MD, Lenardt MHA. Sobrecarga do cuidador familiar de idoso com Alzheimer. Textos Contexto 2011;10(2):388-98.

23. Seima MD, Lenardt MHA, Caldas CP. Relação no cuidado entre o cuidador familiar e o idoso com Alzheimer. Rev Bras Enferm. 2014;67(2):233-40.

Received: January 24, 2016

Reviewed: August 1, 2016

Accepted: November 7, 2016 